\title{
A global analysis of soil moisture derived from satellite observations and a land surface model
}

\author{
K. T. Rebel ${ }^{1,2}$, R. A. M. de Jeu ${ }^{2}$, P. Ciais ${ }^{3}$, N. Viovy ${ }^{3}$, S. L. Piao ${ }^{3}$, G. Kiely ${ }^{4}$, and A. J. Dolman ${ }^{2}$ \\ ${ }^{1}$ Department of Environmental Sciences, Copernicus Institute of Sustainable Development, Utrecht University, \\ Utrecht, The Netherlands \\ ${ }^{2}$ Department of Earth Sciences, Faculty of Earth and Life Sciences, Vrije Universiteit Amsterdam, \\ Amsterdam, The Netherlands \\ ${ }^{3}$ Laboratory for Climate Sciences and the Environment (LSCE), CEA-CNRS-UVSQ, Gif-sur-Yvette, France \\ ${ }^{4}$ Department of Civil \& Environmental Engineering, Centre for Hydrology, Micrometeorology and Climate Change, \\ University College Cork, College Road, Cork, Ireland
}

Correspondence to: K. T. Rebel (k.t.rebel@uu.nl)

Received: 26 March 2011 - Published in Hydrol. Earth Syst. Sci. Discuss.: 29 April 2011

Revised: 6 January 2012 - Accepted: 17 February 2012 - Published: 16 March 2012

\begin{abstract}
Soil moisture availability is important in regulating photosynthesis and controlling land surface-climate feedbacks at both the local and global scale. Recently, global remote-sensing datasets for soil moisture have become available. In this paper we assess the possibility of using remotely sensed soil moisture - AMSR-E (LPRM) - to similate soil moisture dynamics of the process-based vegetation model ORCHIDEE by evaluating the correspondence between these two products using both correlation and autocorrelation analyses. We find that the soil moisture product of AMSR-E (LPRM) and the simulated soil moisture in ORCHIDEE correlate well in space and time, in particular when considering the root zone soil moisture of ORCHIDEE. However, the root zone soil moisture in ORCHIDEE has on average a higher temporal autocorrelation relative to AMSRE (LPRM) and in situ measurements. This may be due to the different vertical depth of the two products - AMSR-E (LPRM) at the $2-5 \mathrm{~cm}$ surface depth and ORCHIDEE at the root zone $(\max .2 \mathrm{~m})$ depth - to uncertainty in precipitation forcing in ORCHIDEE, and to the fact that the structure of ORCHIDEE consists of a single-layer deep soil, which does not allow simulation of the proper cascade of time scales that characterize soil drying after each rain event. We conclude that assimilating soil moisture, using AMSR-E (LPRM) in a land surface model like ORCHIDEE with an improved hydrological model of more than one soil layer, may significantly improve the soil moisture dynamics, which could lead to improved $\mathrm{CO}_{2}$ and energy flux predictions.
\end{abstract}

\section{Introduction}

Changes in land $\mathrm{CO}_{2}$ uptake and emissions at mid latitudes are strongly related to the frequency and magnitude of droughts (Angert et al., 2005) and are, thus, ultimately linked to variations and possible future changes in the global hydrological and carbon cycles. Details of when, where, and how strong this coupling is, are largely unknown. Summer droughts under future climate conditions are likely to increase in frequency and intensity over Europe (Seneviratne at al., 2006b), parts of Northern America and the Mediterranean area according to the IPCC (Solomon et al., 2007), but there is doubt as to whether this is already visible in the observational record (van der Schrier, 2006). Various regions in the world also appear more sensitive to regional and local scale atmospheric feedbacks induced by soil moisture status that can increase the persistence and likelihood of drought (e.g. Koster et al., 2004; Seneviratne et al., 2006a). Albertson et al. (2001) and D'Andrea et al. (2006) even suggest that wet and dry summers may exhibit bimodal distributions of soil moisture. This implies that changes from relatively wet- and carbon fixating conditions- towards dry- and carbon emitting-conditions, may be far more abrupt than previously thought.

Angert et al. (2005) suggest that hydrological processes, such as soil moisture availability, may in fact be more important in the carbon uptake of vegetation than the traditionally studied growth enhancing temperature effects (see also Ciais et al., 2005; Reichstein et al., 2007). Recent land-surface 
modelling intercomparisons point to the need to focus on an accurate description of the soil moisture in the carbon and climate feedbacks (Reichstein et al., 2007). These are currently not adequately capturing the spatial and temporal response of the biosphere. Our lack of understanding of the coupling of the hydrological and carbon cycle is largely due to the lack of adequate soil moisture observations at relevant scales (e.g. subcontinental).

Unfortunately, soil moisture is notoriously difficult to observe with in situ measurements at large scales due to its large spatial and temporal variability, and its variation within the soil profile. Remote sensing of surface soil moisture has the potential to help fill this gap (Wagner et al., 2007). Microwave remote sensing provides the capability for spatial soil moisture observation in the top-soil (upper few centimeters). Microwave measurements have the benefit of being largely unaffected by cloud cover. The most accurate soil moisture estimates are, however, limited to regions that have low to moderate amounts of vegetation cover with a vegetation optical depth at $\mathrm{C}$-band $<0.6$ (NDVI value of about 0.6; De Jeu et al., 2009; Liu et al., 2011a). In the absence of significant vegetation cover (C-band vegetation optical depth $<0.8$ ), soil moisture is the dominant effect on the received signal (Njoku and Entekhabi, 1996). During the last few years several global soil moisture datasets have been published (Njoku et al., 2003; Wagner et al., 2003). These products have different characteristics, depending on satellite technique, and retrieval approach.

A global soil moisture dataset that has recently been developed by Owe et al. (2008) uses a microwave radiative transfer model to retrieve soil moisture from the observed brightness temperatures (Land Parameter Retrieval Model, LPRM). The LPRM has been applied to 29 years of historical microwave data and the retrieved soil moisture has been validated over different parts of the world (De Jeu et al., 2008; Liu et al., 2009). This dataset provides an excellent opportunity to test the performance of global land surface models, working at a similar spatial resolution as the microwave observations.

Since a few years, data from a global network of micrometeorological flux measurement sites have been available for scientists. This dataset is called FLUXNET (see http://www.fluxdata.org) and the set has been extensively used for carbon and energy studies (Baldocchi et al., 2001). Some of the sites have soil moisture information, but the in situ soil moisture data from this data network have so far been overlooked. Within this study we will use the soil moisture information from FLUXNET and explore the quality of this dataset.

In this study we will also use ORCHIDEE, a process-based global land surface model (Krinner et al., 2005), which is being used for simulation of carbon and water fluxes of point locations, in European and global applications (Ciais et al., 2005; Piao et al., 2007). ORCHIDEE simulates fluxes of $\mathrm{CO}_{2}$, water and energy at a half-hourly time step, while the ecosystem carbon and water dynamics (e.g. allocation, plant respiration, growth, mortality, soil organic matter decomposition, water infiltration and runoff) are calculated at a daily time step (Krinner et al., 2005). The remotely sensed soil moisture data are compared to gridded soil moisture modeled by ORCHIDEE, with the goal to study the possibility of using satellite soil moisture data for soil moisture assimilation with ORCHIDEE. Since satellite remote sensing samples only the first few centimeters of soil, we focus on the relative comparisons and the dynamics of the soil moisture depletion processes after rain events. These processes are strongly affected by climate forcing and the soil hydrological characteristics, and give us valuable information on the performance of both the structure of ORCHIDEE in terms of subsurface soil hydrology, and satellite soil moisture. The soil moisture depletion process time varies between a few days to several months and can be characterized with autocorrelation analysis. The general objective of this study is, thus, to evaluate the performance of subsurface hydrology of ORCHIDEE in relation to satellite and in situ soil moisture using both correlation and autocorrelation analysis. These are the necessary required first steps before a full assimilation methodology can be implemented.

\section{Data}

\subsection{Satellite-derived soil moisture}

Satellite observations from the Advanced Microwave Scanning Radiometer (AMSR-E) on board the AQUA satellite are used for soil moisture retrieval. The AQUA satellite was launched in May 2002 and stopped on 4 October 2011. The instrument measures the microwave radiation emitted by the Earth's surface in vertical and horizontal polarization, expressed in terms of brightness temperature. AMSRE provides global passive microwave observations at 6 different frequencies, including $6.9 \mathrm{GHz}$ (C-band), $10.7 \mathrm{GHz}$ (X-band) and the $36.5 \mathrm{GHz}$ (Ka-band). The spatial resolution of the footprint measurements is $56 \mathrm{~km}$ at C-band, 38 $\mathrm{km}$ at X-band and $12 \mathrm{~km}$ at Ka-band. AMSR-E scans the Earth's surface in an ascending (01:30 p.m. LT) and descending (01:30 a.m. LT) mode. Level $2 \mathrm{~A}$ globally swath spatially resampled brightness temperatures (Ascroft and Wentz, 2003) are obtained from the National Snow and Ice Data Center (NSIDC) and used in the Land Parameter Retrieval Model (Owe et al., 2008) to retrieve surface soil moisture of the first centimeters. The LPRM is based on the inversion of the $\omega-\tau$ radiative transfer model (Mo et al., 1982), and uses the internal analytical approach to solve for the vegetation optical depth, $\tau$ (Meesters et al., 2005). This unique feature reduces the required vegetation parameters to one, the single scattering albedo.

The retrieval methodology uses a nonlinear iterative procedure in a forward modeling approach to partition the surface emission into its primary source components, i.e. the 
soil surface and the vegetation canopy, and optimizes on the canopy optical depth and the soil dielectric constant. Once convergence between the calculated and observed brightness temperature is achieved, the model uses a global data base of soil physical properties (Rodell et al., 2004) together with a soil dielectric model (Wang and Schmugge, 1980) to derive surface soil moisture from the optimized dielectric constant. No field observations of soil moisture, canopy biophysical properties, or other observations are used for calibration purposes, making the model largely physically-based with no regional dependence and applicable at any microwave frequency suitable for soil moisture monitoring (i.e. L-, C-, X-, or Ka-band). For this study we used the descending relative to ascending C-band frequency retrievals because this dataset has been shown to be the most reliable soil moisture dataset because the night time observations are less sensitive to temperature fluctuations (Owe et al., 2008; Draper et al., 2009; Liu et al., 2011b). The default C-band derived soil moisture is replaced with the X-band if the grid cell is diagnosed with radio frequency interference (RFI) according to the method of Li et al. (2004). Data between July 2002 and December 2010 were selected and used in this study. The soil moisture retrievals are produced from Level 2A AMSRE swaths with a sampling density of about $0.1^{\circ}$ and a spatial resolution of 74 by $43 \mathrm{~km}$. Daily Earth coverage is nearly $100 \%$ above and below 45 north and south latitudes, while mid latitudes experience about $80 \%$ coverage (Ascroft and Wentz, 2003). The swath soil moisture data are globally averaged and gridded in order to create daily maps at a $0.5^{\circ}$ grid scale. These satellite-derived soil moisture products at the frequencies used here (C- and $\mathrm{X}$-band) are representative of soil moisture of approximately several tenths of a wavelength ( $\sim-2 \mathrm{~cm}$ at C-band; Schmugge, 1983). For clarity, we will name the satellite-derived soil moisture in the rest of the paper AMSR-E (LPRM).

The uncertainty of soil moisture retrieval is a function of the vegetation density and sensor characteristics and was previously estimated to be $0.04 \mathrm{~m}^{3} \mathrm{~m}^{-3}$ for sites with sparse vegetation (LPRM vegetation optical depth $<0.4$ ) to $0.1 \mathrm{~m}^{3} \mathrm{~m}^{-3}$ for regions with moderate to dense (LPRM vegetation optical depth $>0.4$ ) vegetation cover (Parinussa et al., 2011a). The range of soil moisture between a dry and wet state is about 10 times higher $\left(\sim 0.4 \mathrm{~m}^{3} \mathrm{~m}^{-3}\right)$ than the uncertainty. AMSRE (LPRM) observations were calculated with and without a low pass filter (i.e. a 5 day moving average) to quantify the effect of the random noise on the signal. The noise is mainly caused by the accuracy of the instrument itself and partly due to the low revisit time of the satellite. The revisit period of Aqua is 16 days meaning that the satellite will be on the exact same orbit after 16 days. However, the sensor will have a global coverage within two days.

AMSR-E (LPRM) observations are stored in a $0.5^{\circ}$ grid using a nearest neighbor approach, but each gridded observation in time is based on a selection of footprint observations, which represent a slightly different area at each time step.
After 16 days they will see more or less the same region. One part of the soil moisture noise is caused by this issue, which could be resolved with a low pass filter, as done previously by Wagner et al. (2007) and Draper et al. (2009). The global soil moisture product retrieved using the AMSR-E (LPRM) method is well validated with in situ observations, land surface models, and other global satellite-derived soil moisture products over a variety of vegetation covers (e.g. Wagner et al., 2007, De Jeu et al., 2008; Draper et al., 2009; Rüdiger et al., 2009; Dorigo et al., 2010; Mladenova et al., 2011).

\subsection{ORCHIDEE soil moisture}

ORCHIDEE is a process-oriented model of the terrestrial water-carbon-energy cycles. It consists of three sub-models (Krinner et al., 2005). The Soil Vegetation Atmosphere Transfer (SVAT) scheme SECHIBA (Ducoudré et al., 1993; de Rosnay and Polcher, 1998), which calculates water fluxes in the soil-plant-atmosphere continuum and photosynthesis with a $1 / 2$ hourly time step. The STOMATE model (Krinner et al., 2005) describes the carbon dynamics within ecosystems, including allocation of assimilates within plant organs, phenology, mortality, and litter and soil organic carbon decomposition and subsequent respiration, with a daily time step. The third sub-model, describing the long-term dynamics of vegetation, and largely inspired from the LPJ vegetation dynamics (Sitch et al., 2003), is not activated in this study. Rather, vegetation cover is prescribed here from IGBP-DISCover Global Land Cover Classification (GLCC) products (Loveland et al., 2000). Within ORCHIDEE, the global vegetation is described using 12 plant functional types and bare soil. Two distinct plant functional types are governed by the same equations for carbon and water dynamics, but with different parameters. The only exception to this is the leaf onset date (phenology), which is calculated as a function of temperature or soil moisture, using a specific equation for each plant functional type (Botta et al., 2000).

Of main interest in this study for comparison with the satellite-derived soil moisture is the sub-model of surface and sub-surface soil hydrology, which has two soil layers of variable depth: the upper one (normally indicated as GQSB, in this study indicated as SHALLOW_SM) and the lower one (normally indicated as BQSB, in this study indicated as DEEP_SM), the latter fixed to a depth of $2 \mathrm{~m}$ everywhere. SHALLOW_SM acts as a bucket. It only loses water by evapotranspiration. So the speed for water loss is related to the evapotranspiration rate. It is filled by precipitation that reaches the soil (e.g. precipitation that is not intercepted by leaves). So SHALLOW_SM will first fill up until it reaches the surface. Then its depth will increase. If its depth reaches the DEEP_SM pool, the two pools will merge and SHALLOW_SM will disappear. When it rains, SHALLOW_SM fills up with non-intercepted water. When evapotranspiration is larger than precipitation, water is removed for evapotranspiration from this upper layer when available. Otherwise 
the evaporative demand is taken from DEEP_SM, which will always exist and can be saturated or not. However, SHALLOW_SM will disappear after drying out, when all available water has been taken up by the vegetation or has percolated downwards to DEEP_SM. SHALLOW_SM will replenish with rain. Surface runoff occurs when the soil is saturated (Ducoudré et al., 1993).

The maximum amount of water that is available for plant water uptake is $300 \mathrm{~mm}$, which is computed as the difference between soil moisture at field capacity and wilting point in a $2 \mathrm{~m}$ soil profile, and is uniform in space. In other model versions, field capacity can be estimated as a function of surface soil texture, and varies in space, but results are not very different from using a fixed uniform value for this parameter. The potential root water uptake profile differs between grassland and forest, according to a prescribed decreasing exponential function with depth. A residual fraction of $20 \%$ of the maximum potential root uptake is still possible when the bottom layer is almost empty. The variable HUMREL (in this study indicated as ROOT_SM) is defined as the soil moisture that is available in the root profile (exponential decline with depth). In ROOT_SM, the soil moisture is weighted by the average fraction of roots at this level assuming that the total (sum) of root fractions is 1 with the soil depth.

The ORCHIDEE model was forced by the CRU-NCEP dataset (http://dods.extra.cea.fr/data/p529viov/cruncep/ readme.htm). This dataset is based on CRU2.0 monthly climate anomalies at a $0.5^{\circ} \times 0.5^{\circ}$ covering the period 1901 to 2002 (Mitchell and Jones, 2005), and the NCEP reanalysis at a $1^{\circ} \times 1^{\circ}$ covering the period 1948 to 2010 (Kanamistu et al., 2002). The two datasets are combined using the 6 hourly variability of NCEP and the monthly fields of CRU to obtain a pseudo $0.5^{\circ} \times 0.5^{\circ} 6$ hourly dataset covering the period 1901 to 2010.

For the spin up, ORCHIDEE was run using the 1901-1930 climate in loop until equilibrium of water and carbon pools in soil and vegetation was achieved. Note that few years would suffice to equilibrate the water pools, but since the vegetation structure (LAI, biomass) depends on a spin-up carried out over a longer time period, soil moisture is indirectly sensitive to the carbon cycle spin-up length. Then, the simulation was launched using climate from 1901 to 2010 taking into account increasing $\mathrm{CO}_{2}$, which is prescribed uniform in the atmosphere and varies each year according to ice core data and Mauna Loa observations after year 1957 (data compiled by Rayner et al., 2005). ROOT_SM and other relevant model output variables have been archived for the period from 2002 to 2010 at a daily time step for comparison with satellite observations.

\subsection{FLUXNET soil moisture}

FLUXNET is a global network of micrometeorological flux measurement sites that estimate the exchange of carbon dioxide, water vapor, and energy between the biosphere and atmosphere. Vegetation under study includes temperate conifer, broadleaf evergreen and deciduous forests, tropical and boreal forests, crops, grasslands, chaparral, wetlands, and tundra. Sites exist on five continents and their latitudinal distribution ranges from $70^{\circ} \mathrm{N}$ to $30^{\circ} \mathrm{S}$. Data (up to 2007) and site information are available online at the FLUXNET Website, http://www.fluxdata.org (Baldocchi et al., 2001).

Of all available FLUXNET sites (253), 118 sites include soil moisture measurements in the top $30 \mathrm{~cm}$ of the soil. We applied a data selection to ensure data quality. First we selected sites with more than 300 data-points between July 2002 and January 2007, which resulted in 35 sites. Next we ensured the sites were (a) not located near coasts/water bodies (excluding mixed pixels), (b) not located at regions where the AMSR-E (LPRM) sensor was contaminated by radiofrequency interference, and (c) not located in a region with a too high a vegetation density (optical depth $<0.8$, Parinussa et al., 2011a). Finally we visually assessed whether the sites had enough data in winter, and that the sites did not include strange data-jumps due to e.g. change of instruments. This resulted in 15 sites available for this study. These selected sites have a variety of vegetation types and climates. Table 1 lists the selected FLUXNET sites, their coordinates and the vegetation type at the site.

\section{Comparison studies}

\subsection{Setup}

\subsubsection{Correlation between AMSR-E (LPRM) and ORCHIDEE}

For both AMSR-E (LPRM) and ORCHIDEE, half degree soil moisture values have been calculated from July 2002 to December 2010. We have calculated several state variables in ORCHIDEE, i.e. SHALLOW_SM, DEEP_SM, TOT_SM (=SHALLOW_SM + DEEP_SM) and ROOT_SM, and compared these to the AMSR-E (LPRM) values.

The routine for AMSR-E (LPRM) has an output in volumetric soil moisture (in $\mathrm{m}^{3} \mathrm{~m}^{-3}$ ), while for ORCHIDEE the output is in mm available water - except for ROOT_SM, which is defined as a fraction from 0 (dry) to 1 (saturated). To calculate the correspondence between AMRS-E and ORCHIDEE soil moisture, we first calculated the Pearson's correlation coefficient $(r)$ between the daily output values of AMSR-E (LPRM) and the daily soil moisture state variables of ORCHIDEE over 2002-2010. We then computed the anomalies of the AMSR-E (LPRM) as well as the ORCHIDEE output. The anomalies were calculated by decomposing the raw time series data into climatology and anomaly components. For both AMSR-E (LPRM) and ORCHIDEE the climatology for the entire analysis period (i.e. July 2002December 2010) was calculated using a 31 day moving window centered on a particular day of year. The anomalies 
Table 1. Geographical location and characteristics of the 15 FLUXNET study sites as used in the ground validation study.

\begin{tabular}{|c|c|c|c|c|c|c|}
\hline No. & Site name & Lat. & Long. & Vegetation (IGBP class) & $\begin{array}{r}\text { Precip. } \\
\left(\mathrm{mm} \mathrm{yr}^{-1}\right)\end{array}$ & Primary contact/reference \\
\hline 1 & Lethbridge, Canada & $49.71^{\circ} \mathrm{N}$ & $112.94^{\circ} \mathrm{W}$ & Grassland & 398 & $\begin{array}{l}\text { Lawrence Flanagan, Flanagan } \\
\text { and Johnson (2005) }\end{array}$ \\
\hline 2 & Las Majadas del Tietar, Spain & $39.94^{\circ} \mathrm{N}$ & $5.77^{\circ} \mathrm{W}$ & Savanna & 528 & Maria Jose Sanz, Casal et al. (2009) \\
\hline 3 & Vall d'Alinya, Spain & $42.15^{\circ} \mathrm{N}$ & $1.45^{\circ} \mathrm{E}$ & Grassland & 1064 & Gilmanov et al. (2007) \\
\hline 4 & Le Bray, France & $44.72^{\circ} \mathrm{N}$ & $0.77^{\circ} \mathrm{W}$ & Evergreen needleleaf forest & 972 & Berbigier et al. (2001) \\
\hline 5 & Dripsey, Ireland & $51.99^{\circ} \mathrm{N}$ & $8.75^{\circ} \mathrm{W}$ & Grassland & 1450 & Gerard Kiely, Jaksic et al. (2006) \\
\hline 6 & Mitra IV Tojal, Portugal & $38.48^{\circ} \mathrm{N}$ & $8.02^{\circ} \mathrm{W}$ & Grassland & 750 & Gilmanov et al. (2007) \\
\hline 7 & Pang/Lambourne, UK & $51.45^{\circ} \mathrm{N}$ & $1.27^{\circ} \mathrm{W}$ & Deciduous broadleaf forest & 800 & Richard Harding \\
\hline 8 & Lamont, Oklahoma, USA & $35.55^{\circ} \mathrm{N}$ & $98.04^{\circ} \mathrm{W}$ & Grassland & 740 & Marc Fischer \\
\hline 9 & Hainich, Germany & $51.08^{\circ} \mathrm{N}$ & $10.45^{\circ} \mathrm{E}$ & Deciduous broadleaf forest & 780 & Alexander Knohl, Knohl et al. (2003) \\
\hline 10 & Tonzi Range, CA, USA & $38.43^{\circ} \mathrm{N}$ & $120.97^{\circ} \mathrm{W}$ & Savanna & 581 & Dennis Baldocchi, Ma et al. (2007) \\
\hline 11 & Mehrstedt, Germany & $51.27^{\circ} \mathrm{N}$ & $10.66^{\circ} \mathrm{E}$ & Grassland & 695 & Axel Don, Don et al. (2009) \\
\hline 12 & Hartheim, Germany & $47.56^{\circ} \mathrm{N}$ & $7.37^{\circ} \mathrm{E}$ & Pine forest & 600 & Helmut Mayer, Jaeger and Kessler (1997) \\
\hline 13 & Klingenberg, Germany & $50.89^{\circ} \mathrm{N}$ & $13.52^{\circ} \mathrm{E}$ & Cropland & 702 & Christian Bernhofer \\
\hline 14 & Duke Forest, NC, USA & $35.97^{\circ} \mathrm{N}$ & $79.10^{\circ} \mathrm{W}$ & Hardwood & 1169 & Gaby Katul \\
\hline 15 & Metolius Pine, OR, USA & $44.45^{\circ} \mathrm{N}$ & $121.56^{\circ} \mathrm{W}$ & Ponderosa Pine & 522 & Bev Law, Thomas et al. (2009) \\
\hline
\end{tabular}

were calculated by subtracting the (8-year) climatology from the original observations on a particular day (Parinussa et al., 2011b). Next, we analyzed the correlation coefficient of the anomalies between the daily values derived from AMSR-E (LPRM) and the daily soil moisture state variables of ORCHIDEE over 2002-2010. The correlation of both analyses can be skewed due to errors or scale differences in precipitation forcing in ORCHIDEE. This version of ORCHIDEE used CRU-NCEP data, which are $0.5^{\circ}$ monthly CRU data adjusted to daily values using $1^{\circ} \mathrm{NCEP}$ data, while AMSR-E (LPRM) is a more direct measure of surface soil moisture with a better spatial resolution and therefore expected to be more sensitive to actual precipitation events. To identify the accuracy of the CRU-NCEP forcing, we also correlated the CRU-NCEP daily rainfall data to the AMSR-E (LPRM) soil moisture data.

The relationship between ORCHIDEE and AMSR-E (LPRM) varies geographically. To learn more about these differences, we used the FLUXNET data for in situ comparisons with AMSR-E (LPRM) and ORCHIDEE.

\subsubsection{Autocorrelation}

Modeled, satellite and in situ observed soil moisture products do not necessarily have to agree since they are a result of processes at a different spatial scale. For example, a small local rainstorm could have a significant impact on an in situ observation, but only a limited impact at $0.5^{\circ}$ scale. However, despite the differences in spatial scale, in situ, modeled and satellite products should agree in terms of temporal dynamics (e.g. trend) and hence have a similar response to rainfall if the rainfall was equally distributed. An autocorrelation analysis captures the general temporal dynamics of soil moisture and is thus a powerful tool to analyze different soil moisture products, because it describes the direct soil moisture response to hydrological processes, being less sensitive to spatial scaling issues.

For continuous variables we characterize persistence in terms of temporal autocorrelation (lagged correlation), which is the correlation of a variable with its own future and past values (Wilks, 1995). Therefore, a dry-down and rewetting pattern should show similar autocorrelation values if their dynamics are similar, even though the climate forcing might not be timed simultaneously. In this study, the Pearson product-moment correlation coefficient was used to calculate the lagged correlation, where the lag-k autocorrelation coefficient $\left(r_{k}\right)$ can be written as (Wilks, 1995):

$r_{k}=\frac{\sum_{i=1}^{n-k}\left(x_{i} x_{i+k}\right)-(n-k) \bar{x}^{2}}{\sum_{i=1}^{n} x_{i}^{2}-n \bar{x}^{2}}$

where $n$ is the total number of observations in the time series, $i$ is the current observation to be analyzed, $k$ is the lag-time in days (one of the series shifted by $k$ units of time) and $x$ is the observation of the time series. An $r_{k}$ of 1 shows a perfect autocorrelation (autocorrelation of data with itself), and an $r_{k}$ of 0 shows there is no autocorrelation between the original and the shifted original dataset. The characteristic lag-time is the time at which the lag of the autocorrelation function $\left(r_{k}\right)$ reduces to 1/e (0.37) (Delworth and Manabe, 1988; Maurer et al., 2001).

First we calculated the autocorrelation of AMSR-E (LPRM) derived top-soil moisture, ROOT_SM values in ORCHIDEE, and in situ values at the point locations where FLUXNET soil moisture data were available. Next, we calculated the autocorrelation of the anomaly of AMSR-E 
(LPRM) and ROOT_SM at the same point locations. We could only calculate the anomaly autocorrelation for FLUXNET data with time series longer than 2 years. Finally, we calculated the autocorrelation and the anomaly autocorrelation of both AMSR-E (LPRM) and ORCHIDEE for all grids globally.

\subsection{Results and discussion}

\subsubsection{Global correlation of AMSR-E (LPRM) and ORCHIDEE soil moisture}

We analyzed the correlation between daily AMSR-E (LPRM) retrieved top-soil moisture and the different state variables representing different soil moisture quantities calculated in ORCHIDEE, on a daily time step. In Fig. 1a-d, the significant $(p<0.05)$ correlation coefficients are shown between AMSR-E (LPRM) and the ORCHIDEE variables SHALLOW_SM, DEEP_SM, TOT_SM and ROOT_SM. In the northern latitudes, AMSR-E (LPRM) is frequently not receiving a good signal because there is often snow on the ground, which leads to few reliable data points for the comparison. Therefore, we applied a simple Land Surface Temperature filter to mask all cells with $T<273^{\circ} \mathrm{K}$ (Holmes et al., 2009), and masked all cells with less than 100 (daily) data points per year. In areas with dense vegetation (optical depth >0.8), AMSR-E (LPRM) is not reliable (Parinussa et al., 2011a) and therefore masked out completely.

It is clear that both modeled variables TOT_SM and ROOT_SM show the best correlation values with AMSR-E (LPRM) (Fig. 1c and d). SHALLOW_SM and DEEP_SM show somewhat opposite behavior. For dry areas the DEEP_SM is very small and in fact interacts little with the surface since there is never the possibility of a merge between SHALLOW_SM and DEEP_SM. Therefore, in this case the model behaves like a single bucket model represented by the SHALLOW_SM. This explains why we have a relatively good correlation between SHALLOW_SM and AMSR-E (LPRM) and a poor correlation between DEEP_SM and AMSR-E (LPRM) in dry regions. For others regions, the behavior of SHALLOW_SM is more complex and can appear or disappear when merging with DEEP_SM in a relatively random way which explains the poor correlation between SHALLOW_SM and AMSR-E (LPRM) and the good correlation between DEEP_SM and AMSR-E (LPRM), because SHALLOW_SM drains into DEEP_SM. Even though SHALLOW_SM represents a shallow soil layer in the model, the correlation coefficient cannot be calculated at very dry times of the year, because this upper layer does not exist and SHALLOW_SM takes values equal to zero. Therefore, we do not use SHALLOW_SM further in the analysis; rather, we continue with the ORCHIDEE output that showed the best correlation values, ROOT_SM. In large areas of Europe, East Europe, North America, South America and mid to south Africa, the correlation coefficient between
AMSR-E (LPRM) and ROOT_SM is close to one, meaning that the temporal variability of the two products is very closely related. In the northern latitudes, the correlation coefficient takes values between 0 and -1 , which is caused by the fact that frozen soil in ORCHIDEE contains little water, while the water content is retrieved close to saturation in AMSR-E (LPRM). This is caused by the simple applied mask, which has an uncertainty of $\pm 4 \mathrm{~K}$ (Holmes et al., 2009), allowing soils to remain frozen when the surface temperature $>273^{\circ} \mathrm{K}$. In very dry areas (i.e. deserts), we find almost no correlation, since ORCHIDEE simulates no difference in soil moisture, while AMSR-E (LPRM) has a high signal to noise ratio in these regions (De Jeu et al., 2008). The regions where ORCHIDEE and AMSR-E (LPRM) are closely related ( $r$ close to 1$)$, correspond to a comparison of the European Remote Sensing Satellites (ERS) soil moisture products with soil moisture output by the global dynamic vegetation model LPJ (Wagner et al., 2003), as well as the comparison of AMSR-E (LPRM) with the global NOAH shallow soil moisture output (Liu et al., 2011b).

The anomaly analysis (Fig. 1e-h) shows much smaller correlation coefficients (range between $-0.5-0.5$ ) than the correlation between AMSR-E (LPRM) and the different state variables of ORCHIDEE, even though the general geographic pattern is similar. This indicates that the inter-annual variability between AMSR-E (LPRM) and ORCHIDEE agree less, and part of the signal of the correlation coefficient shown in Fig. 1a-d is caused by seasonality. Australia has a high anomaly correlation coefficient when comparing AMSR-E (LPRM) and ROOT_SM. AMSR-E (LPRM) has been shown to have a good signal in this area (Draper et al., 2009; Mladenova et al., 2011), and ORCHIDEE input as well as soil description is probably very suitable for this region, causing an $r$ of nearly 0.5. Although Southern Brazil has been shown to be a difficult area for AMSR-E (LPRM) (Dorigo et al., 2010), the inter-annual variability between AMSR-E (LPRM) and ROOT_SM agree reasonably well.

Correlating the precipitation forcing (CRU-NCEP; with CRU at $0.5^{\circ}$ combined with NCEP at $1^{\circ}$ spatial resolution) to the AMSR-E (LPRM) soil moisture results in r-values between -1 and 1 (Fig. 2). Correlation values are lower than AMSR-E (LPRM) compared with ORCHIDEE ROOT_SM, which is caused both by the uncertainty of the precipitation field, and by the influence of land evaporation. Precipitation forcing fields are highly uncertain, and land surface models are most sensitive to this forcing to calculate soil moisture (Guo and Dirmeyer, 2006). New methods are being developed to improve precipitation forcing along with soil moisture fields, e.g. using satellite-based rainfall accumulation estimates to improve surface soil moisture retrievals (Schumann et al., 2009), and sometimes including the use of hydrological models (Crow et al., 2009; Parajka et al., 2009). Evaporation is highly important for the seasonal soil moisture cycle, as soil moisture is not only driven by precipitation but also by soil water uptake (Miralles et al., 2011). 

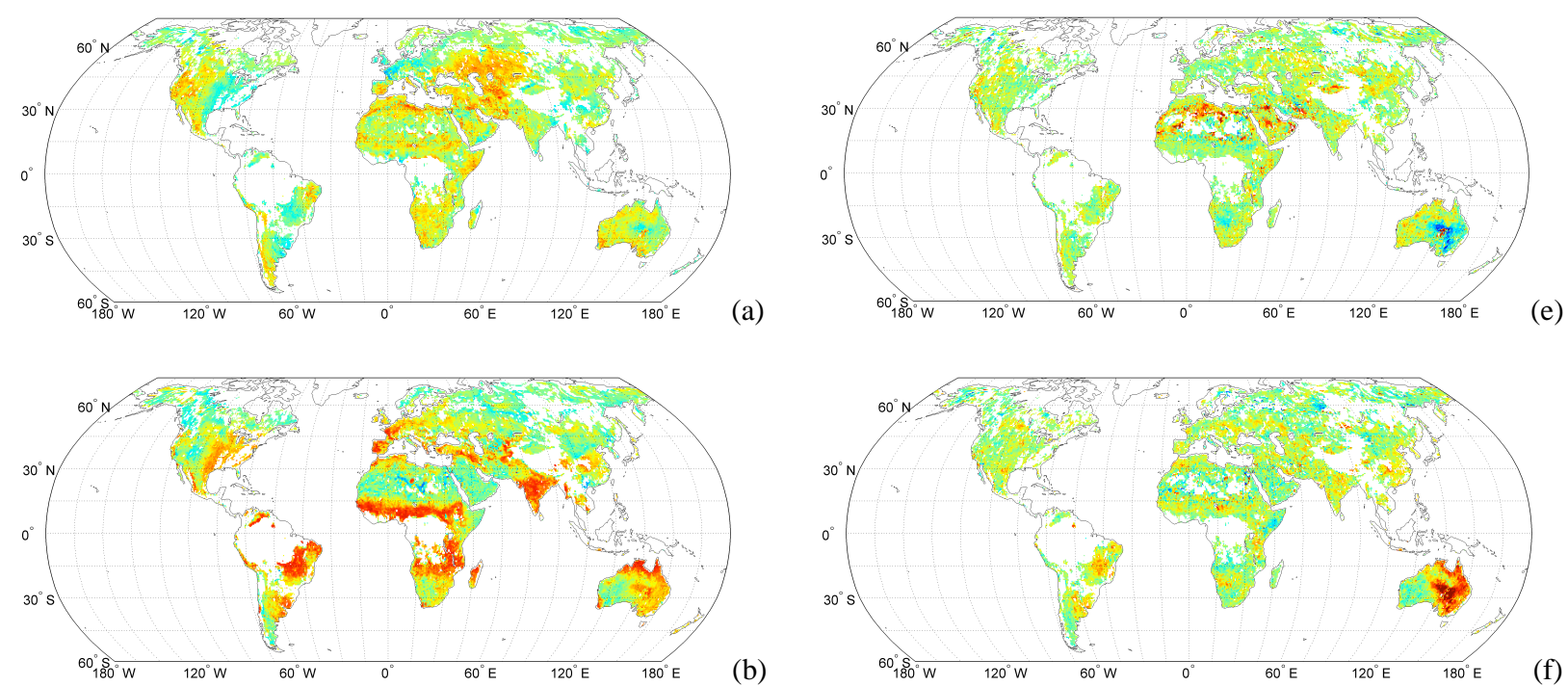

e)
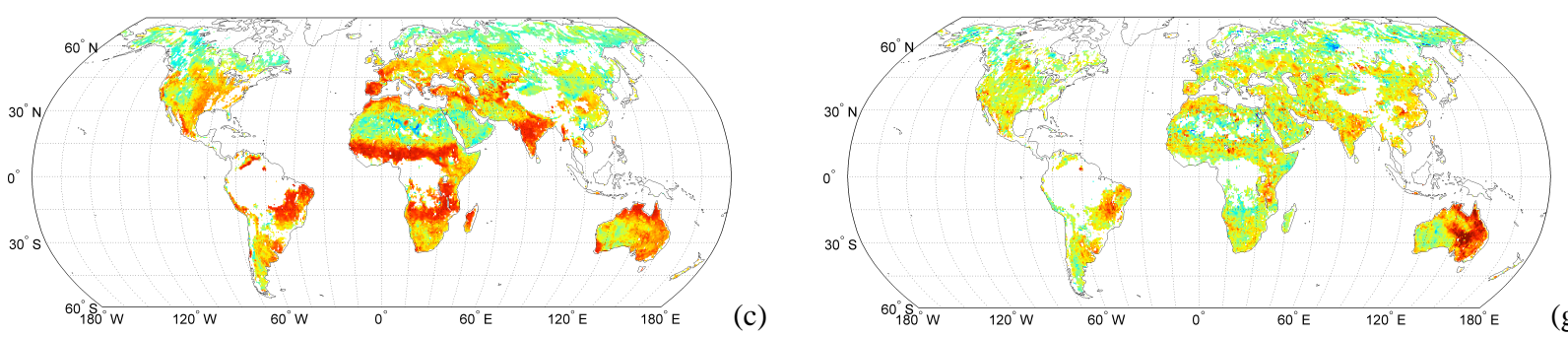

(g)
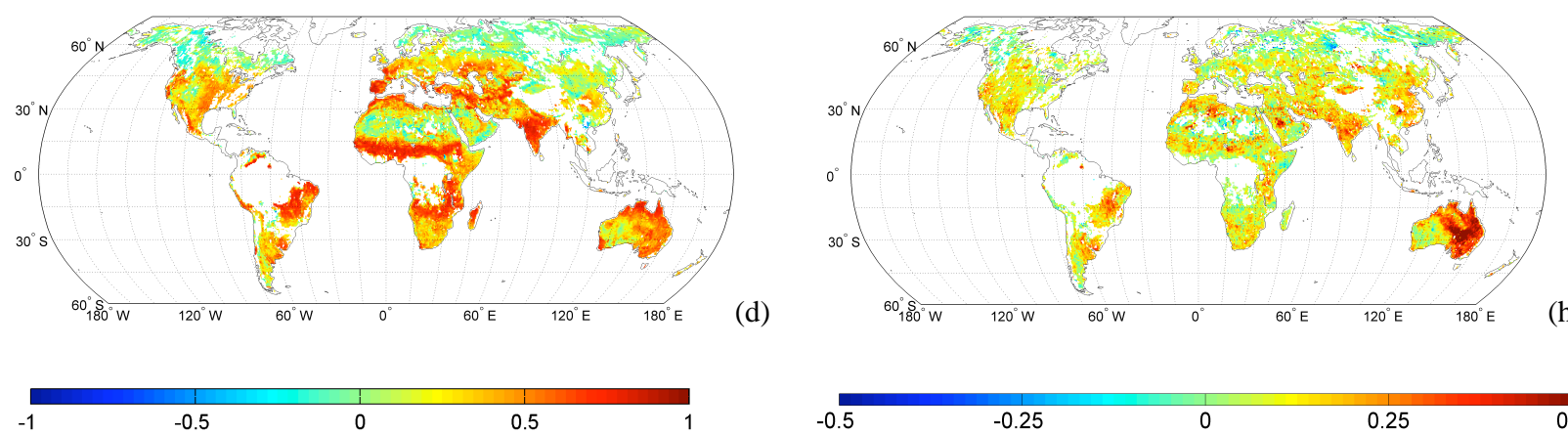

0.25

0.5

Fig. 1. (a)-(d): Global correlation coefficient maps of AMSR-E (LPRM) versus the ORCHIDEE soil moisture parameters SHALLOW_SM, DEEP_SM, TOT_SM and ROOT_SM for the time period 2002-2010. (e)-(h): Global correlation coefficient maps of the anomalies of AMSR-E (LPRM) versus the ORCHIDEE soil moisture parameters SHALLOW_SM, DEEP_SM, TOT_SM and ROOT_SM for the time period 2002-2010.

\subsubsection{Evaluation with in situ data}

The Pearson's correlation coefficients between the soil moisture observations at the FLUXNET locations and AMSR-E (LPRM) and ROOT_SM are shown in Table 2. AMRS-E (LPRM) and ROOT_SM values are compared with available FLUXNET data between June 2002 and December 2007. The variability in correlation between in situ and modeled/satellite soil moisture is large, ranging from $r=0.13$ in a cropland in Klingenberg, Germany, to $r=0.92$ in a Pine forest in CA, USA. We calculated the $r$ of AMSR-E (LPRM) with in situ data with and without a 5-day moving average on AMSR-E (LPRM), to see the difference when accounting for the noise on AMSR-E (LPRM) and found that a 5day moving average did not make a significant difference for these sites. No significant relation can be found between the value of the correlation coefficient and vegetation cover, and it seems that the order of the value of the correlation coefficient is mainly determined by the existence of local processes such as land cover heterogeneity and subgrid precipitation events affecting each site. The correlation coefficients for 
Table 2. Pearson's correlation coefficient (r), and characteristic lag-times (ch. lag) in days of the FLUXNET in situ measurements, AMRS-E (LPRM) and ORCHIDEE (ROOT_SM).

\begin{tabular}{|c|c|c|c|c|c|c|c|c|c|c|c|}
\hline \multirow[t]{2}{*}{ No } & \multirow[t]{2}{*}{ Site Name } & \multirow{2}{*}{$\begin{array}{l}\text { In Situ } \\
\text { ch. lag }\end{array}$} & \multicolumn{4}{|c|}{ AMSR-E (LPRM) } & \multicolumn{3}{|c|}{ ORCHIDEE (ROOT_SM) } & \multirow{2}{*}{$\begin{array}{r}N \\
\text { days }\end{array}$} & \multirow[t]{2}{*}{ Period } \\
\hline & & & $r$ & $r(\text { mov. av. })^{*}$ & $r(\text { ano. })^{*}$ & ch. lag & $r$ & $r(\text { ano. })^{*}$ & ch. lag & & \\
\hline 1 & Lethbridge, Canada & 33 & 0.33 & 0.44 & 0.48 & 5 & 0.51 & 0.13 & 59 & 804 & Jul 2002-Jan 2006 \\
\hline 2 & Majadas del T, Spain & 48 & 0.87 & 0.88 & 0.49 & 49 & 0.73 & 0.15 & 66 & 408 & Jan 2005-Jan 2007 \\
\hline 3 & Vall dl Alinya, Spain & 14 & 0.44 & 0.51 & 0.28 & 20 & 0.51 & 0.19 & 40 & 445 & Mar 2004-Jan 2007 \\
\hline 4 & Le Bray, France & 47 & 0.60 & 0.72 & 0.07 & 51 & 0.76 & 0.12 & 75 & 487 & Jan 2005-Jan 2007 \\
\hline 5 & Dripsey, Ireland & 51 & 0.44 & 0.65 & 0.09 & 2 & 0.79 & 0.63 & 45 & 437 & Jan 2003-Jan 2006 \\
\hline 6 & Mitra IV Tojal, Port. & 67 & 0.80 & 0.80 & 0.67 & 62 & 0.82 & 0.42 & 59 & 493 & Jan 2005-Jan 2007 \\
\hline 7 & Pang/Lambourne, UK & 60 & 0.54 & 0.76 & 0.19 & 19 & 0.89 & 0.07 & 71 & 593 & Jan 2005-Jan 2007 \\
\hline 8 & Lamont, OK, USA & 85 & 0.47 & 0.48 & 0.49 & 62 & 0.31 & 0.22 & 23 & 574 & Jan 2003-Nov 2006 \\
\hline 9 & Hainich, Germany & 55 & 0.46 & 0.53 & 0.47 & 23 & 0.81 & 0.49 & 65 & 1011 & Jul 2002-Jan 2007 \\
\hline 10 & Tonzi Range, CA, USA & 62 & 0.60 & 0.67 & 0.34 & 32 & 0.92 & 0.64 & 64 & 773 & Jul 2002-Jan 2007 \\
\hline 11 & Mehrstedt, Germany & 51 & 0.55 & 0.65 & 0.14 & 34 & 0.62 & 0.00 & 54 & 704 & Sep 2003-Jan 2007 \\
\hline 12 & Hartheim, Germany & 51 & 0.48 & 0.53 & 0.13 & 42 & 0.78 & 0.29 & 42 & 492 & Jan 2005-Jan 2007 \\
\hline 13 & Klingenberg, Germany & 10 & 0.43 & 0.43 & 0.45 & 9 & 0.13 & 0.15 & 66 & 393 & Jan 2005-Jan 2007 \\
\hline 14 & Duke Forest, NC, USA & 53 & 0.65 & 0.65 & 0.34 & 53 & 0.52 & 0.43 & 17 & 601 & Jul 2003-Jan 2006 \\
\hline 15 & Metolius Pine, OR, USA & 63 & 0.59 & 0.67 & 0.21 & 44 & 0.93 & 0.41 & 67 & 493 & Jul 2004-Dec 2005 \\
\hline
\end{tabular}

*mov. av. $=5$ day moving average, ano. $=$ anomalies

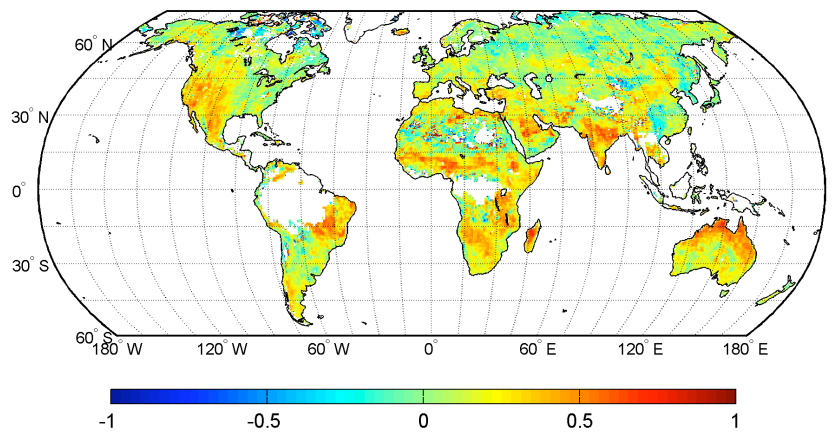

Fig. 2. Global Pearson's correlation coefficient maps of AMSR-E versus the CRU-NCEP precipitation forcing of ORCHIDEE.

ORCHIDEE are generally higher than for AMSR-E (LPRM) (on average 0.67 and 0.55 respectively), which may indicate that the FLUXNET measurements, which are taken in the top $30 \mathrm{~cm}$, are more comparable to the depth of the ORCHIDEE root zone soil moisture than to the $2-5 \mathrm{~cm}$ surface soil moisture of AMSR-E. However, Cosh et al. (2006) suggest that at least 16 soil moisture stations are needed to obtain a reliable spatially averaged soil moisture value at a $0.25^{\circ}$ scale. Here, just a single observation is analyzed in comparison with $0.5^{\circ}$ averaged satellite observations and care should be taken in the interpretation of these results. A temporal autocorrelation signature is likely to be spatially more stable and thus a more a powerful tool for data analysis when a dense soil moisture network is not present.

The soil moisture autocorrelation was calculated as the lag-k autocorrelation coefficient $\left(r_{k}\right)$ for the in situ FLUXNET measurements, the satellite AMSR-E (LPRM) retrievals, and the ORCHIDEE ROOT_SM simulated variable at each FLUXNET site (Tables 1 and 2). In Fig. 3, we show the time series and in Fig. 4 the autocorrelation plots of these different variables for sites in Spain, France, Portugal, Germany and the USA. The time series shows the temporal dynamics of the different variables. In the autocorrelation plots (Fig. 4), on the y-axes $r_{k}$ is shown, which is a measure of autocorrelation (Eq. 1). On the x-axes, the lag-time in days is shown for the corresponding autocorrelation values. The characteristic lag-time is the lag at which the autocorrelation function $\left(r_{k}\right)$ reduces to $1 / e(0.37)$ (Delworth and Manabe, 1988; Maurer et al., 2001), which is represented by the black dashed horizontal line. For example, at the Portuguese site, AMSR-E (LPRM) (blue), ORCHIDEE (red) and the in-situ data (black) have a characteristic lag-time of around 60 days, which means that the "soil memory" is 60 days.

In Fig. 4, ORCHIDEE and FLUXNET show an excellent agreement in autocorrelation at the sites in Portugal, Germany and the USA, suggesting that the model captures the temporal dynamics of soil moisture on synoptic to seasonal scales well. On the other hand, AMSR-E (LPRM) has lower characteristic lag-times than FLUXNET data on the German and the USA sites, but agrees well on the Spanish, French and Portuguese sites. Annual rainfall and plant functional type do not seem to explain this behavior.

The time series for the in-situ FLUXNET measurements generally do not exceed a 2-year time period, which is too short for the anomaly autocorrelation calculation. However, we do have a 4.5 years-long time series for Hainich, Germany, for which we show the anomaly autocorrelation in Fig. 5. Even though the autocorrelation has a high similarity for in-situ and ORCHIDEE (Fig. 4), this signal is most likely dominated by the seasonal cycle as can be seen by the dissimilarity of in-situ and ORCHIDEE when addressing anomaly autocorrelation (Fig. 5). Figure 6 compares the in situ 

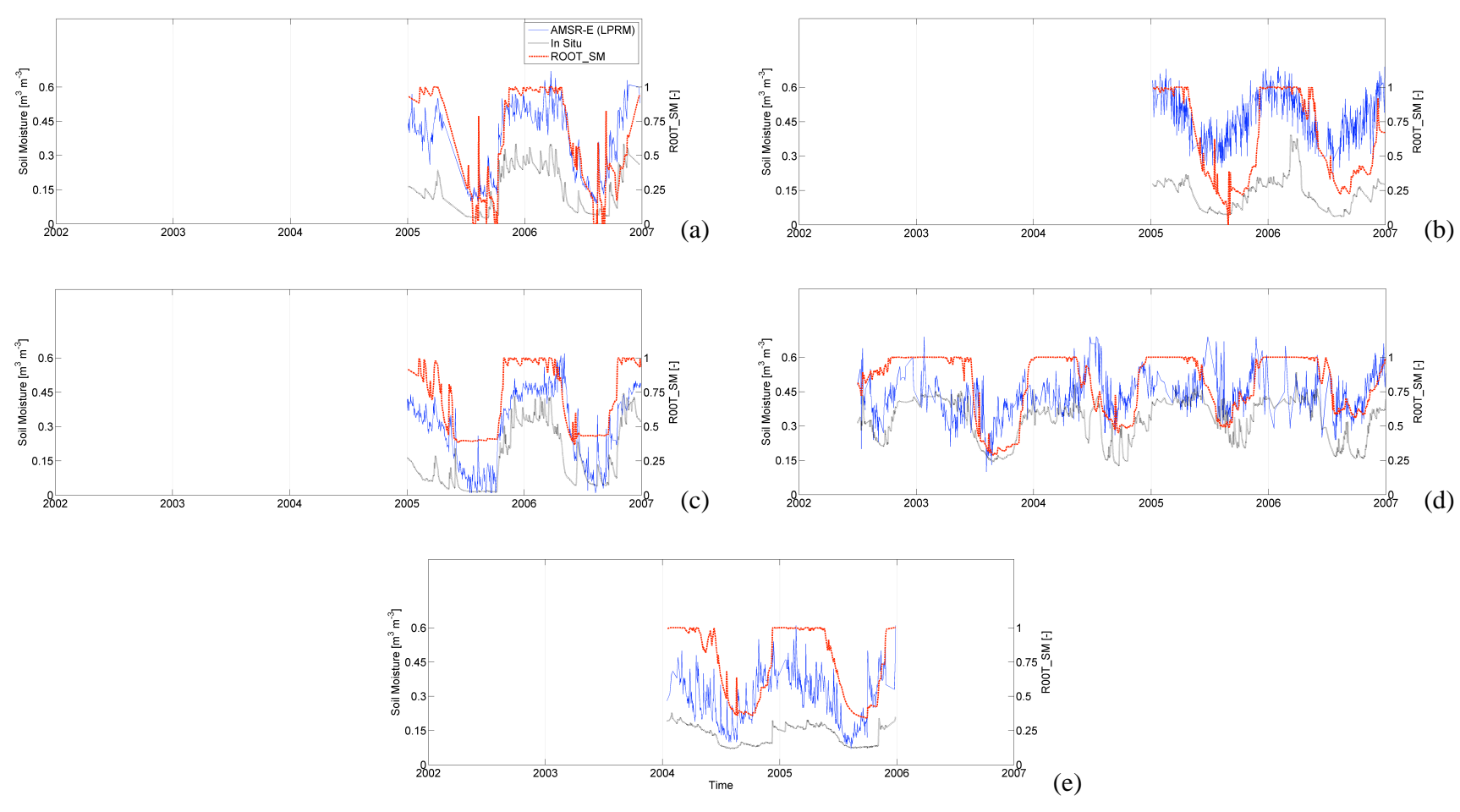

Fig. 3. Time series of AMSR-E, ORCHIDEE ROOT_SM and in situ FLUXNET soil moisture data of (a) Majadas del T, Spain (\# 2), (b) Le Bray, France (\# 4), (c) Mitra IV, Portugal (\# 6), (d) Hainich, Germany (\# 9) and (e) Metolius Pine, USA, (\# 15).

FLUXNET characteristic lag-time versus the characteristic lag-time of satellite AMSR-E (LPRM) soil moisture, and modeled ROOT_SM variables, for the 15 sites. The crosssites correlation coefficient of the characteristic lag-time between in situ and AMSR-E (LPRM) is higher $(r=0.61)$, than the correlation coefficient of the characteristic lag-time between in situ and ROOT_SM $(r=-0.16)$. This demonstrates a higher correspondence in the autocorrelation signature between in situ FLUXNET and satellite observations, indicating that both have a similar response to the hydrological processes. The autocorrelation signature of ROOT_SM is significantly different, generally showing a lower temporal dynamic in the model, mostly dictated by its sub-surface hydrology. This can be expected from a mono-layer bucket, which is also indicative for the ORCHIDEE hydrology, since the top layer is often empty. Figure 6 shows that the model bias is rather constant for AMSR-E (LPRM), which always has a lower characteristic time than in-situ measurements. In contrast, ORCHIDEE generally has longer characteristic lag times than FLUXNET sites, except for two sites in the USA, Lamont, Oklahoma (740 $\mathrm{mm} \mathrm{yr}^{-1}$ precip) and Duke forest, North Carolina (1169 $\mathrm{mm} \mathrm{yr}^{-1}$ precip). The longer characteristic lag-times by ORCHIDEE could be due to (1) unrealistic (too smooth) rainfall forcing from CRU-NCEP model (i.e. underestimated precipitation variability because of unresolved rainstorms; (2) structural rigidity in soil moisture dynamics calculation of ORCHIDEE (i.e. not enough surface runoff or lack of temporally variable root water uptake); in particular the unique deep soil layer imposes a single residence time for water in the soil with respect to plant transpiration removal, whereas in reality, each soil layer has its own residence time; (3) misfit between modeled and observed soil moisture because ORCHIDEE only provides root-zone integrated values, which will show less variability than top-soil values, while AMSR-E (LPRM) and the measurements reflect more shallow soil moisture dynamics, which are characterized by short term variability and thus short characteristic lag-times (Wu and Dickinson, 2004; De Lannoy et al., 2006). This is confirmed by Wagner et al. (1999) who found mean correlations between 0.35 to 0.53 and 0.33 to 0.49 when comparing ERS scatterometer data with gravimetric soil moisture measurements in Ukraine in $0-20 \mathrm{~cm}$ and $0-100 \mathrm{~cm}$ layers respectively. The introduction of a multi-layer soil moisture model within ORCHIDEE with a better description of top-soil moisture dynamics might be a logical next step in model development. This could lead to a better assimilation of the entire soil moisture profile, which would result in a more direct one to one comparison with in situ and satellite observations.

\subsubsection{Global autocorrelation maps}

It is assumed that the autocorrelation function $r_{k}$ becomes insignificant when it takes values lower than $1 / e$, also shown in Figs. 4 and 5. In Fig. 7a and b, the characteristic lag-time 

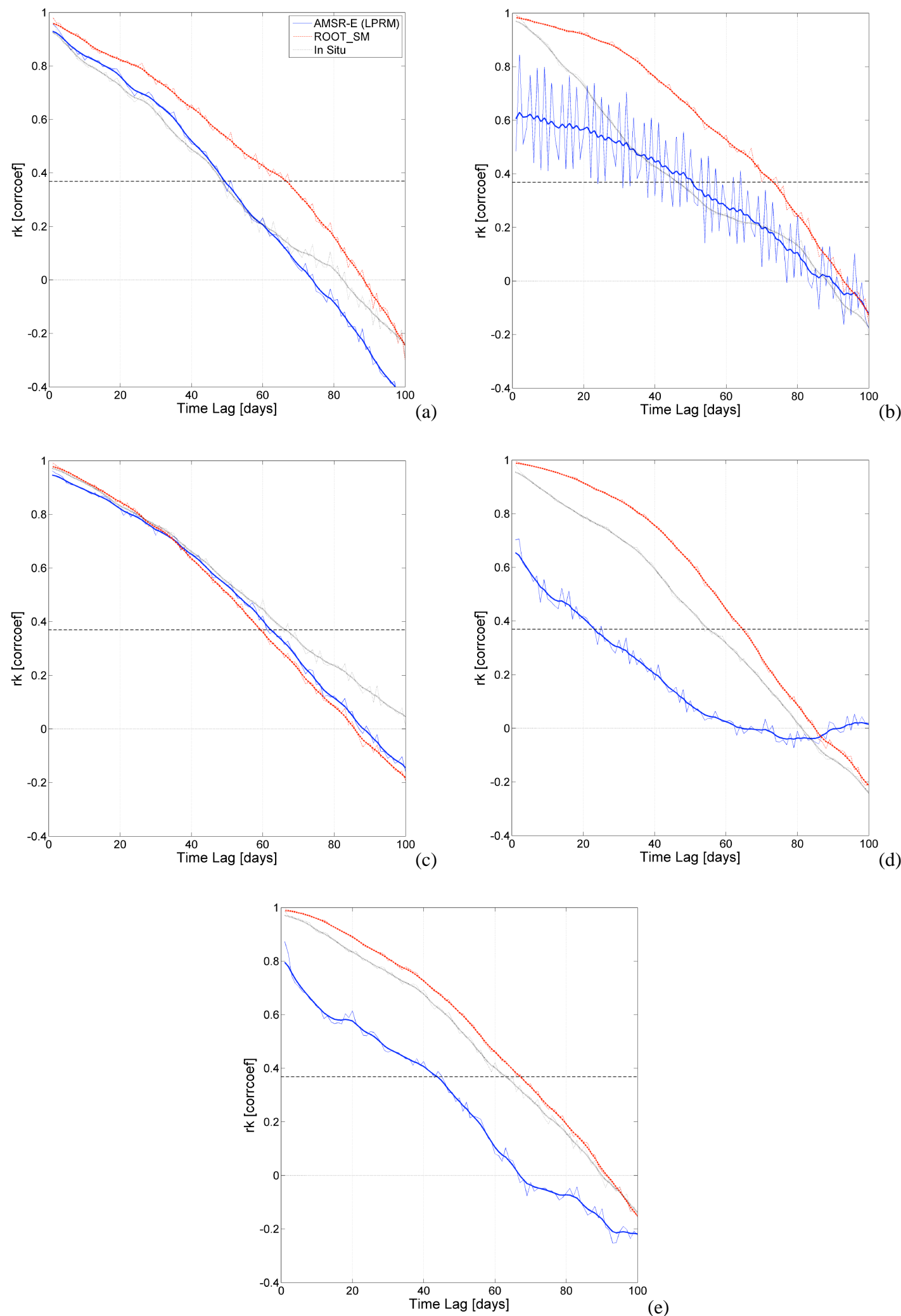

Fig. 4. Autocorrelation graphs of AMSR-E, ORCHIDEE ROOT_SM and in situ FLUXNET soil moisture data of (a) Majadas del T, Spain (\# 2), (b) Le Bray, France (\# 4), (c) Mitra IV, Portugal (\# 6), (d) Hainich, Germany (\# 9) and (e) Metolius Pine, USA, (\# 15). Black dashed horizontal line in autocorrelation graphs indicates where the rk value is equal to $1 / e$, indicating the characteristic lag-time at the $\mathrm{x}$-axis. 


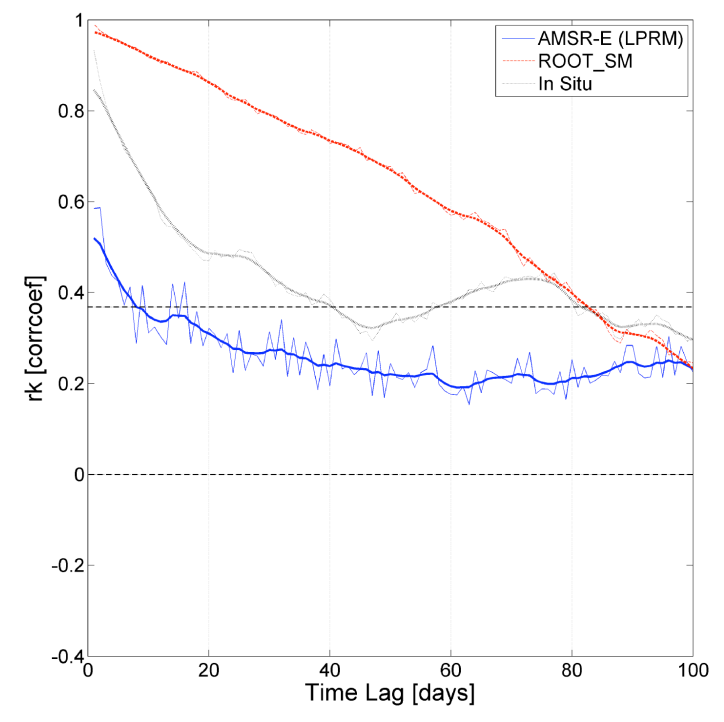

Fig. 5. Anomaly autocorrelation for the Deciduous broadleaf forest site Hainich in Germany. Black dashed horizontal line in autocorrelation graph indicate where the rk value is equal to $1 / e$, indicating the characteristic lag-time at the $\mathrm{x}$-axis, and where the $r k$ value is equal to 0 , indicating at which lag ( $\mathrm{x}$-axis) the autocorrelation has been lost.

is plotted on each grid point for 2002-2010. In general, the lag-time in ROOT_SM is longer than in AMSR-E (LPRM), with differences of up to 50 days. Figure $7 \mathrm{c}$ and $\mathrm{d}$ show the autocorrelation value at a 20-day lag for ORCHIDEE ROOT_SM (Fig. 7c) and AMSR-E (LPRM) (Fig. 7d). This shows a very similar trend as Fig. 7a and b, now showing that ORCHIDEE ROOT_SM has high autocorrelation values at a 20-day lag, while AMSR-E (LPRM) autocorrelation has decreased to values below 0.4. Both analyses suggest a discrepancy due to the deeper soil depth in ROOT-SM, which produces a slower moisture removal after rain compared to AMSR-E (LPRM).

Overall, the slow decrease of soil moisture after rain in ORCHIDEE may suggest that this model will underestimate the response of vegetation to dry spells in the future, and hence may underestimate the positive feedback of climate change on the carbon cycle as well. In the recent coupled carbon-climate models intercomparison of Friedlingstein et al. (2006), ORCHIDEE indeed shows a smaller positive feedback compared to other models. At face value, the too slow characteristic lag-time also reflects some inconsistency between what is modeled (total soil moisture content) and what is observed (top-soil moisture). In that respect, it would help to incorporate a multi-layer soil hydrology in ORCHIDEE, as defined for instance by de Rosnay and Polcher (1998) and Orgeval et al. (2008).

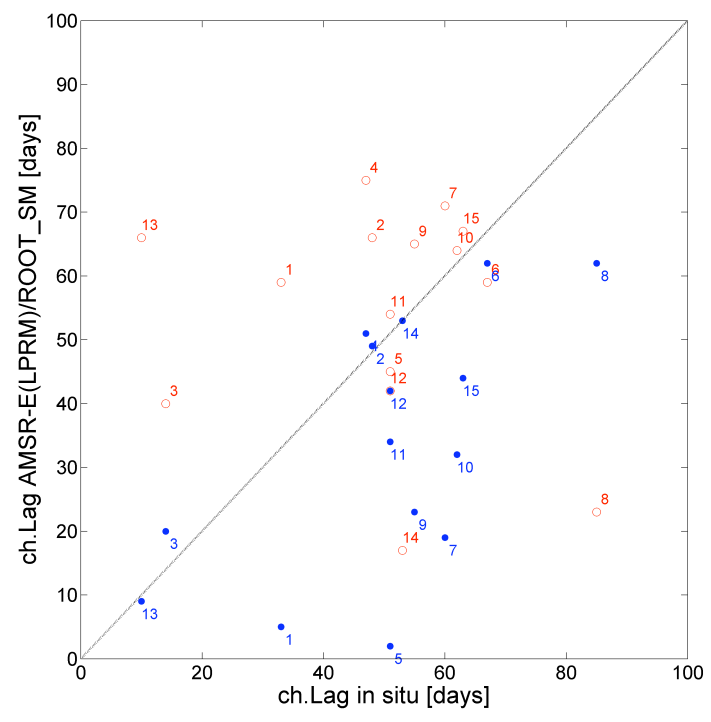

Fig. 6. Characteristic lag-time of FLUXNET in situ soil moisture against characteristic lag-time of AMSR-E (blue) and ROOT_SM (red). The numbers correspond to the site-numbers in Table 1.

\section{Conclusions and summary}

It has been shown that the daily soil moisture product of AMSR-E (LPRM) and simulations of ORCHIDEE forced by CRU-NCEP correlate well in time, within known errors of both, with correlation coefficients $r$ greater than 0.6 for $30 \%$ of the land area. However, correlation is known to be sensitive to outliers and general trends. When we study the temporal characteristics of the two soil moisture products, they are quite different. Remotely sensed soil moisture has a much faster reaction time and much shorter characteristic lag-time than the soil moisture in ORCHIDEE. The characteristic lagtime of remotely sensed soil moisture corresponds well to the in-situ surface FLUXNET soil moisture. These results can be explained by the assumption that AMSR-E (LPRM) represents the upper $5 \mathrm{~cm}$ of soil at most, while ROOT_SM represents the root zone profile, generally the first meter of soil. In conclusion, we find that the remotely sensed soil moisture data compare well to the gridded soil moisture data modeled by the global dynamic vegetation model ORCHIDEE when looking at correlation, while they do not agree when also considering the temporal characteristics of the signal. The temporal response of ORCHIDEE to hydrological processes is different from the in situ and satellite observations.

This study demonstrates the potential to improve global land surface models with satellite soil moisture observations, because these observations appear to capture the existing temporal dynamics in soil moisture well. In the near future, satellite soil moisture observations might be used in a data assimilation routine to improve the soil moisture dynamics of the land surface model, similar to the assimilation of MODIS leaf area index (Demarty et al., 2007). This study shows that 


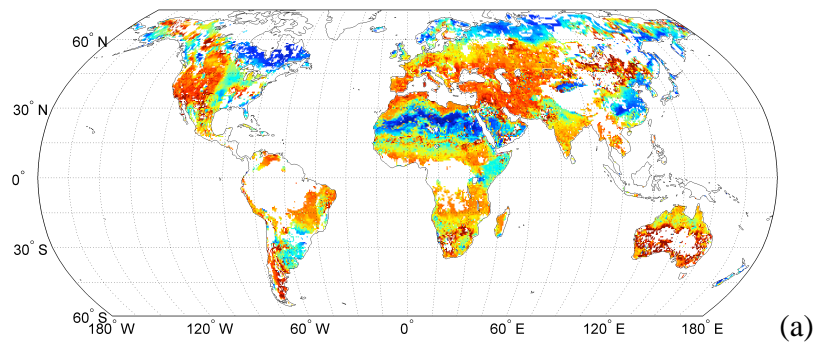

(a)

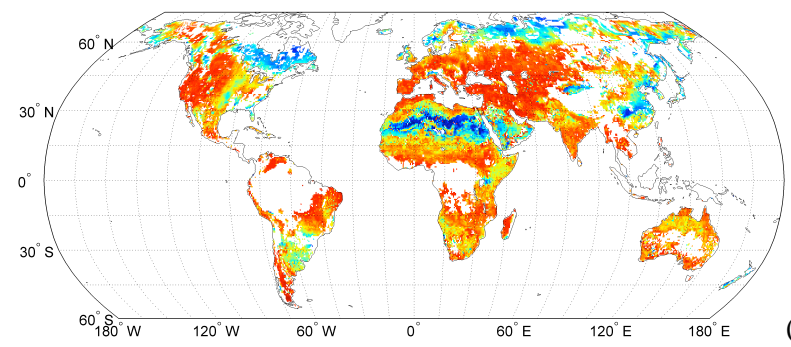

(c)

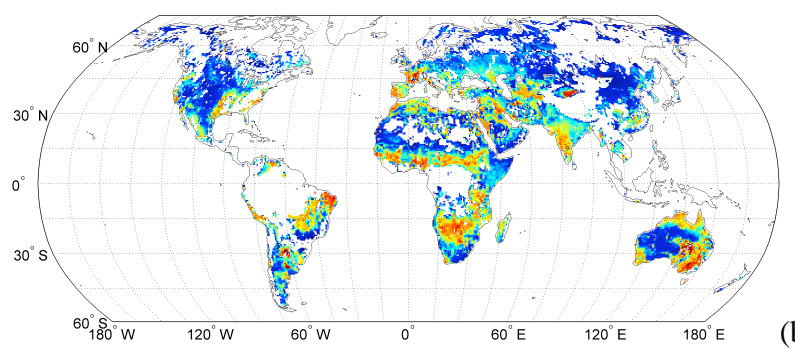

(b)

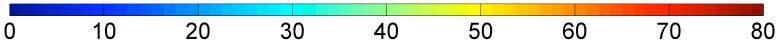

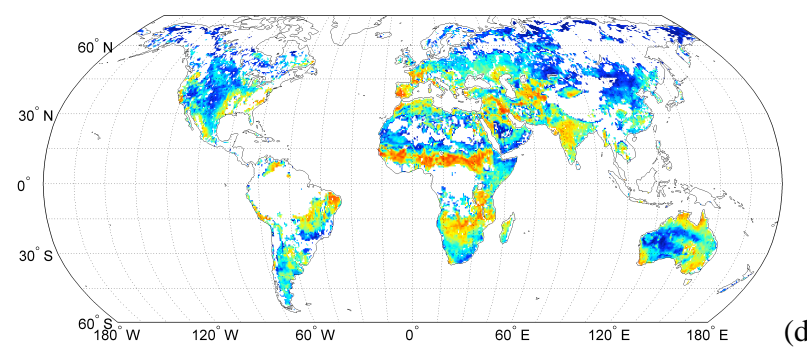

(d)

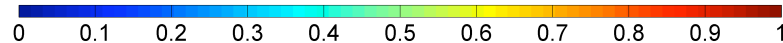

Fig. 7. Global characteristic lag-time (days) for ORCHIDEE ROOT_SM (a) and AMSR-E (LPRM) (b), as well as the autocorrelation value at a 20-day lag for ORCHIDEE ROOT_SM (c) and AMSR-E (LPRM) (d).

this will most likely result in a better description of the biogeochemical processes. Structural model developments to explicitly better account for soil moisture dynamics in the upper soil layers (in particular a multilayered sub-surface soilhydrology; de Rosnay and Polcher, 1998), would need to be executed to be able to assimilate the soil moisture data. This could result in a significant improvement of the terrestrial hydrological cycle of the model. Global satellite soil moisture observations could be used as well to evaluate models for the characteristic drying times of soils after rainfall, a critical variable that will determine the future availability of moisture in soils in a warmer world, and hence the feedbacks between climate and the carbon cycle in coupled models.

Acknowledgements. The research leading to these results has received funding from the European Community's Seventh Framework Programme (FP7/2007-2013) under grant agreement no. 226701 (CARBO-Extreme). We also thank the PIs of the Fluxnet sites who allowed us to use their data for the validation of the model and satellite observations. The Metolius fluxnet site was funded by the US Department of Energy's Office of Science (BER; grant DE-FG02-06ER64318).

Edited by: J. Liu

\section{References}

Albertson, J. D. and Kiely, G.: On the structure of soil moisture time series in the context of land surface models, J. Hydrol., 243, 101-119, 2001.

Angert, A., Biraud, S., Bonfils, C., Henning, C. C., Buermann, W., Pinzon, J., Tucker, C. J., and Fung, I.: Drier summers cancel out the $\mathrm{CO}_{2}$ uptake enhancement induced by warmer springs, $\mathrm{P}$. Natl. Acad. Sci. USA, 102, 10823-10827, 2005.

Ashcroft, P. and Wentz, F.: AMSR-E/Aqua L2A Global Swath Spatially-Resampled Brightness Temperatures (Tb) V001, September to October 2003, National Snow and Ice Data Center, Digital media (Updated daily), Boulder, CO, USA, 2003.

Baldocchi, D., Falge, E., Gu, L., Olson, R., Hollinger, D., Running, S., Anthoni, P., Bernhofer, C., Davis, K., Evans, R., Fuentes, J., Goldstein, A., Katul, G., Law, B., Lee, X., Malhi, Y., Meyers, T., Munger, W., Oechel, W., Paw, K. T. U., Pilegaard, K., Schmid, H. P., Valentini, R., Verma, S., Vesala, T., Wilson, K., and Wofsy, S.: FLUXNET: A new tool to study the temporal and spatial variability of ecosystem-scale carbon dioxide, water vapor, and energy flux densities, B. Am. Meteorol. Soc., 82, 2415-2434, 2001.

Berbigier, P., Bonnefond, J. M., and Mellmann, P.: $\mathrm{CO}_{2}$ and water vapour fluxes for 2 years above Euroflux forest site, Agr. Forest Meteorol., 108, 183-197, 2001.

Botta, A., Viovy, N., Ciais, P., Friedlingstein, P., and Monfray, P.: A global prognostic scheme of leaf onset using satellite data, Global Change Biol., 6, 709-725, 2000.

Casal, P., Gimeno, C., Carrara, A., L'opez-Sangil, L., and Sanz, M. J.: Soil $\mathrm{CO}_{2}$ efflux and extractable organic carbon fractions under simulated precipitation events in a Mediterranean Dehesa, Soil Biol. Biochem., 41, 1915-1922, 2009. 
Ciais, P., Reichstein, M., Viovy, N., Granier, A., Ogée, J., Allard, V., Aubinet, M., Buchmann, N., Bernhofer, C., Carrara, A., Chevallier, F., De Noblet, N., Friend, A. D., Friedlingstein, P., Grünwald, T., Heinesch, B., Keronen, P., Knohl, A., Krinner, G., Loustau, D., Manca, G., Matteucci, G., Miglietta, F., Ourcival, J. M., Papale, D., Pilegaard, K., Rambal, S., Seufert, G., Soussana, J. F., Sanz, M. J., Schulze, E. D., Vesala, T., and Valentini, R.: Europe-wide reduction in primary productivity caused by the heat and drought in 2003, Nature 437, 529-533, 2005.

Cosh, M. H , Jackson, T. J., Starks, P., and Heathman, G.: Temporal stability of surface soil moisture in the Little Washita River watershed and its applications in satellite soil moisture product validation, J. Hydrol., 323, 168-177, 2006.

Crow, W. T., Huffman, G. F., Bindlish, R., and Jackson, T. J.: Improving satellite rainfall accumulation estimates using spaceborne soil moisture retrievals, J. Hydrometeorol., 10, 199-212, 2009.

D'Andrea, F., Provenzale, A., Vautard, R., and De Noblet, N.: Hot and cool summers: Multiple equilibria of the continental water cycle, Geophys. Res. Lett., 33, L24807, doi:10.1029/2006GL027972, 2006.

d'Orgeval, T., Polcher, J., and de Rosnay, P.: Sensitivity of the West African hydrological cycle in ORCHIDEE to infiltration processes, Hydrol. Earth Syst. Sci., 12, 1387-1401, doi:10.5194/hess-12-1387-2008, 2008.

De Jeu, R. A. M., Wagner, W. W., Holmes, T. R. H., Dolman, A. J., van de Giesen, N. C., and Friesen, J.: Global Soil Moisture Patterns Observed by Space Borne Microwave Radiometers and Scatterometers, Surv. Geophys., 28, 399-420, doi:10.1007/s10712-008-9044-0, 2008.

De Jeu, R. A. M., Holmes, T. R. H., Panciera, R., and Walker, J. P.: Parameterization of the Land Parameter Retrieval Model for LBand Observations Using the NAFE'05 Data Set, IEEE Geosci. Remote S., 6, 630-634, doi:10.1109/LGRS.2009.2019607, 2009.

De Lannoy, G. J. M., Verhoest, N. E. C., Houser, P. R., Gish, T. J., and Van Meirvenne, M.: Spatial and temporal characteristics of soil moisture in an intensively monitored agricultural field (OPE3), J. Hydrol., 331, 719-730, doi:10.1016/j.jhydrol.2006.06.016, 2006.

de Rosnay, P. and Polcher, J.: Modelling root water uptake in a complex land surface scheme coupled to a GCM, Hydrol. Earth Syst. Sci., 2, 239-255, doi:10.5194/hess-2-239-1998, 1998.

Delworth, T. L. and Manabe, S.: The influence of potential evaporation on the variabilities of simulates soil wetness and climate, J. Climate, 1, 523-547, 1988

Demarty, J., Chevallier, F., Friend, A. D., Viovy, N., Piao, S., and Ciais, P.: Assimilation of global MODIS leaf area index retrievals within a terrestrial biosphere model, Geophys. Res. Lett., 34, L15402, doi:10.1029/2007GL030014, 2007.

Don, A., Rebmann, C., Kolle, O., Scherer-Lorenzen, M., and Schultze, E-D.: Impact of afforestation-associated management changes on the carbon balance of grassland, Global Change Biol. 15, 1990-2002, doi:10.1111/j.1365-2486.2009.01873.x, 2009.

Dorigo, W. A., Scipal, K., Parinussa, R. M., Liu, Y. Y., Wagner, W., de Jeu, R. A. M., and Naeimi, V.: Error characterisation of global active and passive microwave soil moisture datasets, Hydrol. Earth Syst. Sci., 14, 2605-2616, doi:10.5194/hess-142605-2010, 2010.
Draper, C. S., Walker, J. R., Steinle, P. J., De Jeu, R. A. M., and Holmes, T. R. H.: Evaluation of AMSR-E derived soil moisture over Australia, Remote Sens. Environ., 113, 703-710, doi:10.1016/j.rse.2008.11.011, 2009.

Ducoudré, N. I., Laval, K., and Perrier, A.: SECHIBA, a new set of parameterizations of the hydrologic exchanges at the landatmosphere interface within the LMD atmospheric general circulation model, J. Climate, 6, 248-273, 1993.

Flanagan, L. B. and Johnson, B. G.: Interacting effects of temperature, soil moisture and plant biomass production on ecosystem respiration in a northern temperate grassland, Agr. Forest Meteorol., 130, 237-253, 2005.

Friedlingstein, P., Cox, P., Betts, R., Bopp, L., Von Bloh, W., Brovkin, V., Cadule, P., Doney, S., Eby, M., Fung, I., Bala, G., John, J., Jones, C., Joos, F., Kato, T., Kawamiya, M., Knorr, W., Lindsay, K., Matthews, H. D., Raddatz, T., Rayner, P., Reick, C., Roeckner, E., Schnitzler, K.-G., Schnur, R., Strassmann, K., Weaver, A. J., Yoshikawa, C., and Zeng, N.: Climate-Carbon Cycle Feedback Analysis: Results from the C4MIP Model Intercomparison, J. Climate, 19, 3337-3353, 2006.

Gilmanov, T. G., Soussana, J. F., Aires, L., Allard, V., Ammann, C., Balzarolo, M., Barcza, Z., Bernhofer, C., Campbell, C. L., Cernusca, A., Cescatti, A., Clifton-Brown, J., Dirks, B. O. M., Dore, S., Eugste, W., Fuhrer, J., Gimeno, C., Gruenwald, T., Haszpra, L., Hensen, A., Ibrom, A., Jacobs, A. F. G., Jones, M. B., Lanigan, G., Laurila, T., Lohila, A., Manca, G., Marcolla, B., Nagy, Z., Pilegaard, K., Pinter, K., Pio, C., Raschi, A., Rogiers, N., Sanz, M. J., Stefani, P., Sutton, M., Tuba, Z., Valentini, R., Williams, M. L., and Wohlfahrt, G.: Partitioning European grassland net ecosystem $\mathrm{CO}_{2}$ exchange into gross primary productivity and ecosystem respiration using light response function analysis, Agr. Ecosyst. Environ., 121, 93-120, 2007.

Guo, Z. and Dirmeyer, P. A.: Evaluation of the Second Global Soil Wetness Project soil moisture simulations: 1. Intermodel comparison, J. Geophys. Res., 111, D22S02, doi:10.1029/2006JD007233, 2006.

Holmes, T. R. H, De Jeu, R. A. M., Owe, M., and Dolman, A. J.: Land Surface Temperatures from Ka-Band $(37 \mathrm{GHz})$ Passive Microwave Observations, J. Geophys. Res., 114, D04113, doi:10.1029/2008JD010257, 2009.

Jaeger, L. and Kessler, A.: Twenty years of heat and water balance climatology at the Hartheim pine forest, Germany, Agr. Forest Meteool., 84, 25-36, 1997.

Jaksic, V., Kiely, G., Albertson, J., Katul, G., and Oren, R.: Net ecosystem exchange of grassland in contrasting wet and dry years, Agr. Forest Meteorol., 139, 323-334, 2006.

Kanamitsu, M., Ebisuzaki, W., Woollen, J., Yang, S.-K., Hnilo, J. J., Fiorino, M., and Potter, G. L.: NCEP-DEO AMIP-II Reanalysis (R-2), M. Bul. Atmos. Metol. Soc., 1631-1643, 2002.

Knohl, A., Schulze, E.-D., Kolle, O., and Buchmann, N.: Large carbon uptake by an unmanaged 250-year-old deciduous forest in Central Germany, Agr. Forest Meteorol., 118, 151-167, 2003.

Koster, R. D., Dirmeyer, P. A., Guo, Z., Bonan, G., Chan, E., Cox, P., Gordon, C. T., Kanae, S., Kowalczyk, E., Lawrence, D., Liu, P., Lu, C., Malyshev, S., McAvaney, B., Mitchell, K., Mocko, D., Oki, T., Oleson, K., Pitman, A., Sud, Y. C., Taylor, C. M., Verseghy, D., Vasik, R., Xue, Y., and Yamada, T.: Regions of strong coupling between soil moisture and precipitation, Science, 305, 1138-1140, 2004. 
Krinner, G., Viovy, N., De Noblet-Ducoudré, N., Ogée, J., Polcher, J., Friedlingstein, P., Ciais, P., Sitch, S., and Prentice, I. C.: A dynamic global vegetation model for studies of the coupled atmophere-biosphere system, Global Biogeochem. Cy., 19, GB1015, doi:10.1029/2003GB002199, 2005.

Loveland, T. R., Reed, B. C., Brown, J. F., Ohlen, D. O., Zhu, Z., Yang, L., and Merchant, J. W.: Development of a global land cover characteristics database and IGBP DISCover from $1 \mathrm{~km}$ AVHRR data, Int. J. Remote Sens., 716, 1303-1330, 2000.

Li, L., Njoku, E. G., Im, E., Chang, P. S., and St. Germaine, K.: A preliminary survey of radio-frequency interference over the U.S. in Aqua AMSR-E data, IEEE T. Geosci. Remote, 42, 380390, 2004

Liu, Y., Van Dijk, A. I. J. M., De Jeu, R. A. M., and Holmes, T. R. H.: An Analysis on Spatiotemporal Variations of Soil and Vegetation Moisture from a 29 year Satellite Derived Dataset over Mainland Australia, Water Resour. Res., 45, W07405, doi:10.1029/2008WR007187, 2009.

Liu, Y. Y., De Jeu, R. A. M., McCabe, M. F., Evans, J. P., and Van Dijk, A. I. J. M.: Global long-term passive microwave satellitebased retrievals of vegetation optical depth, Geophys. Res. Lett., 38, L18402, doi:10.1029/2011GL048684, 2011a.

Liu, Y. Y., Parinussa, R. M., Dorigo, W. A., De Jeu, R. A. M., Wagner, W., van Dijk, A. I. J. M., McCabe1, M. F., and Evans J. P.: Developing an improved soil moisture dataset by blending passive and active microwave satellite-based retrievals, Hydrol. Earth Syst. Sci., 15, 425-436, 2011b, http://www.hydrol-earth-syst-sci.net/15/425/2011/.

Ma, S., Baldocchi, D. D., Xu, L., and Hehn, T.: Inter-annual variability in carbon dioxide exchange of an oak/grass savanna and open grassland in California, Agr. Forest Meteorol., 147, 157$171,2007$.

Maurer, E. P., O’Donnell, G. M., Lettenmaier, D. P., and Roads, J. O.: Evaluation of NCEP/NCAR reanalysis water and energy budgets using macroscale hydrologic model simulations, in: Land surface hydrology, meteorology, and climate: observation and modeling, edited by: Lakshmi, V., Albertson, J., and Schaake, J., AGU, Washington, D.C., 137-158, doi:10.1029/WS003p0137, 2001.

Meesters, A. G. C. A., De Jeu, R. A. M., and Owe, M.: Analytical Derivation of the Vegetation Optical Depth from the Microwave Polarization Difference Index, IEEE Geosci. Remote S., 2, 121123, 2005.

Miralles, D. G., De Jeu, R. A. M., Gash, J. H., Holmes, T. R. H., and Dolman, A. J.: Magnitude and variability of land evaporation and its components at the global scale, Hydrol. Earth Syst. Sci., 15, 967-981, doi:10.5194/hess-15-967-2011, 2011.

Mitchell, T. D. and Jones, P. D.: An improved method of constructing a database of monthly climate observations and associated high-resolution grids, Int. J. Climatol., 25, 693-712, 2005.

Mladenova, I., Lakshmi, V., Jackson, T. J., Walker, J. P., Merlin, O., and De Jeu, R. A. M.: Validation of AMSR-E Soil Moisture Using L-band Airborne Radiometer Data from NAFE'06, Remote Sens. Environ., 115, 2096-2103, 2011.

Mo, T., Choudhury, B. J., Schmugge, T. J., Wang, J. R., and Jackson, T. J.: A Model for Microwave Emission from VegetationCovered Fields, J. Geophys. Res., 87, 229-237, 1982.

Njoku, E. G. and Entekhabi, D.: Passive microwave remote sensing of soil moisture, J. Hydrol., 184, 101-129, doi:10.1016/0022-
1694(95)02970-2, 1996.

Njoku, E. G., Jackson, T. J., Lakshmi, V., Chan, T. K., and Nghiem, S. V.: Soil moisture retrieval from AMSR-E, IEEE T. Geosci. Remote, 41, 215-229, 2003.

Owe, M., De Jeu, R., and Holmes, T.: Multi-Sensor Climatology of Satellite-Derived Global Land Surface Moisture, J. Geophys. Res., 113, F01002, doi:10.1029/2007JF000769, 2008.

Parajka, J., Naeimi, V., Blöschl, G., and Komma, J.: Matching ERS scatterometer based soil moisture patterns with simulations of a conceptual dual layer hydrologic model over Austria, Hydrol. Earth Syst. Sci., 13, 259-271, doi:10.5194/hess-13-259-2009, 2009.

Parinussa, R., Meesters, A. G. C. A., Liu, Y. Y., Dorigo, W., Wagner, W., and De Jeu, R. A. M.: An analytical solution to estimate the error structure of a global soil moisture data set, IEEE Geosci. Remote S., 8, 779-783, 2011a.

Parinussa, R. M., Holmes, T. R. H., Yilmaz, M. T., and Crow, W. T.: The impact of land surface temperature on soil moisture anomaly detection from passive microwave observations, Hydrol. Earth Syst. Sci., 15, 3135-3151, doi:10.5194/hess-153135-2011, 2011b.

Piao, S., Friedlingstein, P., Ciais, P., de Noblet-Ducoudré, N., Labat, D., and Zaehle, S.: Changes in climate and land use have a larger direct impact than rising $\mathrm{CO}_{2}$ on global river runoff trends, $\mathrm{P}$. Natl. Acad. Sci. USA, 104, 15242-15247, 2007.

Rayner, P. J., Scholze, M., Knorr, W., Kaminski, T., Giering, R., and Widmann, H.: Two decades of terrestrial Carbon fluxes from a Carbon Cycle Data Assimilation System (CCDAS), Global Biogeochem. Cy., 19, GB2026, doi:10.1029/2004GB002254, 2005.

Reichstein, M., Papale, D., Valentini, R., Aubinet, M., Bernhofer, C., Knohl, A., Laurila, T., Lindroth, A., Moors, E., Pilegaard, K., and Seufert, G.: Determinants of terrestrial ecosystem carbon balance inferred from European eddy covariance flux sites, Geophys. Res. Lett., 34, L01402, doi:10.1029/2006GL027880, 2007.

Rodell, M, Houser, P. R., Jambor, U., Gottschalck, J., Mitchell, K., Meng, C. J., Arsenault, K., Cosgrove, B., Radakovich, J., Bosilovich, M., Entin, J. K., Walker, J. P., Lohmann, D., and Toll, D.: The global land data assimilation system, B. Am. Meteorol. Soc., 85, 381-394, 2004.

Rüdiger, C., Calvet, J. C., Gruhier, C., Holmes, T. R. H., De Jeu, R. A M., and Wagner W. W.: An Intercomparison of ERS-Scat, AMSR-E Soil Moisture Observations with Model Simulations over France, J. Hydrometeorol., 10, 431-448, doi:0.1175/2008JHM997.1, 2009.

Schmugge, T. J.: Remote sensing of soil moisture: Recent advances, IEEE T. Geosci. Remote, 21, 336-344, 1983.

Schumann, G., Lunt, D. J., Valdes, P. J., de Jeu, R. A. M., Scipal, K., and Bates, P. D.: Assessment of soil moisture fields from imperfect climate models with uncertain satellite observations, Hydrol. Earth Syst. Sci., 13, 1545-1553, doi:10.5194/hess-131545-2009, 2009.

Seneviratne, S. I., Koster, R. D., Guo, Z., Dirmeyer, P. A., Kowalczyk, E., Lawrence, D., Liu, P., Mocko, D., Lu, C., Oleson, K. W., and Verseghy, D.: Soil Moisture Memory in AGCM Simulations: Analysis of Global Land-Atmosphere Coupling Experiment (GLACE) Data, J. Hydrometeorol., 7, 1090-1112, 2006a.

Seneviratne, S. I., Lüthi, D., Litschi, M., and Schär, C.: Landatmosphere coupling and climate change in Europe, Nature, 443, 
205-209, 2006b.

Sitch, S., Smith, B., Prentice, I. C., Arneth, A., Bondeau, A., Cramer, W., Kaplan, J. O., Levis, S., Lucht, W., Sykes, M. T., Thonicke, K., and Venevsky, S.: Evaluation of ecosystem dynamics, plant geography and terrestrial carbon cycling in the LPJ dynamic global vegetation model, Global Change Biol., 9, 161$185,2003$.

Solomon, S., Qin, D., Manning, M., Chen, Z., Marquis, M., Averyt, K. B., Tignor, M., and Miller, H. L.: Contribution of Working Group I to the Fourth Assessment Report of the Intergovernmental Panel on Climate Change, Cambridge University Press, Cambridge, UK and New York, NY, USA, 2007.

Thomas, C. K., Law, B. E., Irvine, J., Martin, J. G., Pettijohn, J. C., and Davis, K. J.: Seasonal hydrology explains interannual and seasonal variation in carbon and water exchange in a semiarid mature ponderosa pine forest in Central Oregon, J. Geophys. Res., 114, G04006, doi:10.1029/2009JG001010, 2009.

van der Schrier, G., Briffa, K. R., Osborn, T. J., and Cook, E. R.: Summer moisture availability across North America, J. Geophys. Res., 111, D11102, doi:10.1029/2005JD006745, 2006.
Wagner, W., Lemoine, G., and Rott, H.: A Method for Estimating Soil Moisture from ERS Scatterometer and Soil Data, Remote Sens. Environ., 70, 191-207, 1999.

Wagner, W., Scipal, K., Pathe, C., Gerten, D., Lucht, W., and Rudolf, B.: Evaluation of the agreement between the first global remotely sensed soil moisture data with model and precipitation data, J. Geophys. Res., 108, 4611, doi:10.1029/2003JD003663, 2003.

Wagner, W., Naeimi, V., Scipal, K., de Jeu, R., and MartinezFernandez, J.: Soil Moisture from Operational Meteorological Satellites, Hydrogeol. J., 15, 121-131, doi:1007/s10040-0060104-6, 2007.

Wang, J. R. and Schmugge, T. J.: An empirical-model for the complex dielectric permittivity of soils as a function of water content, IEEE T. Geosci. Remote, 18, 288-295, 1980.

Wilks, D. S.: Statistical methods in the atmospheric sciences, Academic Press, 51-54, 1995.

Wu, W. and Dickinson, R. E.: Time scales of layered soil moisture memory in the context of land-atmosphere interaction, J. Climate, 17, 2752-2764, 2004. 